\title{
The Goods of Human Sexuality: Ethics and Moral
} Theology

\author{
Ellen Wondra ${ }^{1}$ \\ ellen.wondra@seabury.edu
}

\begin{abstract}
Christian ethics has always taken a complex view of the goods and purposes of human sexuality and its role in human relationships. Sexual desire and behavior have to be seen always within the overarching moral imperatives of love of God and love of neighbor. Such love entails self-giving and other-regard, and in longer-term relationships also some measure of commitment, fidelity, reciprocity or mutuality, truthfulness and generativity. Yet not all relationships with these characteristics do (or should) include sexual behavior. Nor do all sexual relationships include all these characteristics or virtues all the time. So we do better to base our moral evaluations of relationships on the exercise of these virtues than on more obvious criteria of sexual orientation or even status in the eyes of the church. At the same time, it is also possible for faithful and reasonable people to disagree faithfully and reasonably on sexual ethics, as on other things.

KEYWORDS: sexuality, homosexuality, Anglican, episcopal, ethics
\end{abstract}

What is the good of human sexuality? What is good human sexuality? What is the point of sex? And what does sexuality have to do with love of God and love of neighbor? Perhaps there have been times in the history of Christianity when these questions had obvious or easy answers. For many Christians today, the answers are neither easy nor obvious.

Throughout history, Christian ethics has centered its consideration of human sexuality in committed monogamous lifelong heterosexual

1. Ellen Wondra is Professor of Theology and Ethics, Seabury-Western Theological Seminary, Evanston, IL, USA and also Editor in Chief of the Anglican Theological Review. 
Christian marriage. Such marriage has been normative, in that it has provided the standard on the basis of which sexual desire and behavior have been evaluated. Such marriage, seen biblically and theologically, has the potential to signify Christ's union with the Church. It is also a manner of life that may be beneficial to the individuals involved and to the larger society of which they are a part; and it may serve as a school for human relationships. But even within this understanding of Christian marriage, for some major strands of ethics, sexuality is only a good insofar as it is open to procreation. For other major strands, sexuality is both a good in itself and a means of achieving other goods and purposes, including for example such things as commitment, fidelity, mutual joy and comfort.

What Christian ethics does not say is that (a) every committed monogamous lifelong heterosexual Christian marriage leads toward these goods; or (b) only committed monogamous lifelong heterosexual Christian marriage leads toward these goods. Nor do ethicists say that human sexual desire can be moral only within this form of marriage. Further, because Christian ethics is about how people may lead a moral Christian life in the midst of the changes and chances of human existence, ethicists recognize that ideally normative forms of relationship (such as sexuality within a particular understanding of marriage) may not be possible for some people in some situations. At least as important is the insight that God does not intend the same manner of life for all Christians, nor even the same manner of life for any one person over the course of a lifetime. (Childhood, for example, is not valued as a permanent manner of life.)

So it is necessary to look at what characterizes a morally good intimate human relationship (such as marriage may be), and how these characteristics are connected with love of God and neighbor.

All morally good human relationships are characterized, minimally, by mutual regard and respect and by an appropriate degree of truthfulness in self-presentation and other-regard. That is, in good relationships, each person sees the other as fully human, fully endowed with dignity, and fully worthy of being treated as such. Beyond this, each person presents her or himself as who she or he is, and sees the other in the same way. Even the most fleeting relationships - passing someone on the sidewalk, picking up the dry cleaning - ought to bear these characteristics. That not all relationships do so may be evidence of human sinfulness. It is certainly evidence of human limitation.

Longer-lasting relationships - professional, ecclesial, social, friendly, intimate - ought to have other characteristics as well if they are to be judged as adequately moral within a Christian framework. Some degree 
of responsibility, loyalty, accountability, attentiveness and availability are needed. For relationships to endure over a period of years, there is need for some type of commitment, fidelity, reciprocity (mutuality), and capacity for the relationship to open up beyond the people most closely connected (what is often called generativity).

A commitment is a promise to bind the future. It is fundamentally a relational term. When I make a commitment, I promise another that my future will have a particular shape and not any other: it will be in accord with what I have promised. Fidelity entails my being worthy of your trust (one meaning of faith) and of my practicing what I have promised in a consistent, continual way. Mutuality or reciprocity means that I offer you what you offer me - not as an exchange such as one might find in a contract, but as a free gift, inspired by self- and other-regard (love). Openness beyond the immediate relationship occurs when those in relationship enhance each other's God-given full humanity. In turn, this is an outgrowth of love of God - that desire for God inherent in being human - practiced in love of neighbor as oneself - desire for the other's well-being even as for one's own.

In fact, all of these characteristics are outgrowths of desire, desire for the good of the other, for the good of the self, for the good of the whole; and all these desires spring from the fact that human beings are, by creation, fundamentally and unavoidably constituted by relationships - relationship with God who creates, sustains and redeems humanity, and relationships with other creatures, human and not. Only in and through relationships are persons fully human; and human desire is a longing and reaching out for that reality. To varying degrees, godly or moral relationships signify the love that Christ has for the Church in that they are in different ways self-giving, otherregarding, unfailing, faithful and free.

It is worth noting that the characteristics that sustain long-lasting relationships are also the 'goods' of committed monogamous lifelong heterosexual Christian marriage. But it is important to note that these characteristics are not found only there. We are fortunate to see them in the ever-changing relationships between parents and children, in the diversity of friendships, in lives lived in intentional communities (such as religious orders), and in relationships formed in pursuit of common goals and common welfare (such as work, civil and social relationships) and, of course, in intimate relations of various sorts, some of them including sexual behavior. Love, in other words, may be found and nurtured and expressed in many places, in many ways and in many degrees of intensity.

So what about sex? What about sexual desire and sexual behavior? All joking aside, it is important to begin by asking what we mean by 
'sex'. The answer is not self-evident. Do we mean sexual intercourse open to procreation that results in male ejaculation? Do we mean fervent sexual desire free from sexual contact (the 'lust in the heart' of Mt. 5.27-29)? Generally, 'sex' refers to a range of feelings and activities that include these two possibilities. On what grounds, then, is it possible to determine what is ethical sexuality and what is not?

At their best, sexual desire and sexual behavior enhance the qualities that characterize moral relationships; they are, in the language of moral theology, ordered or oriented toward those qualities. Such ordering may be found where desire may not be a factor or may not be recognized; and it is true where sexual behavior may be absent or deliberately curtailed. And of course such ordering or orientation may be found in other situations as well, such as those where desire is a factor but behavior is not, or where both desire and behavior are factors.

At their worst, sexual desire and sexual behavior diminish and even destroy the qualities that characterize moral relationships. As much as sexuality, created by God for the good of humanity, may enhance and fulfill our humanity, it may also distort and destroy it. And this latter possibility is present even within what Christian ethics has prescribed as normative: committed monogamous lifelong heterosexual Christian marriage.

This indicates a larger moral insight: outward manner of life by itself does not indicate that a person or a relationship is adequately moral. To some extent the converse is also true: outward manner of life by itself may not indicate that a person or a relationship is to be judged immoral. That is, what is considered a moral relationship in one culture in which the church ministers may be considered an immoral relationship in another. And in its ethics and pastoral theology, the church has always recognized that the concrete circumstances of people's lives must be taken into account when providing moral and pastoral guidance and even judgment. In our own time and place, the Episcopal Church's provision for remarriage after divorce, even among clergy, is a familiar example both of the importance of cultural context and the importance of personal circumstance.

All this suggests that the basic criteria for evaluating any relationship have to do with the extent to which key relational components are present and expressed in ways appropriate to the particular relationship. Mutual regard, respect and truthfulness are minimums for any relationship. Relationships that are more than fleeting ought also to involve responsibility, loyalty, accountability, attentiveness and availability. Long-enduring relationships require commitment, fidelity, reciprocity, forgiveness and generativity. 
Sexual desire may be part of any relationship. It is how that desire affects the well-being of all parties involved that ought to be the basis of evaluating the moral character of sexuality. The criterion here is the extent to which sexual desire and sexual expression (physical or otherwise) tend toward the greatest well-being of all involved - wellbeing of heart, mind and spirit as well as of body. This criterion recognizes that the well-being of each depends on the well-being of all. It also rules out violence, coercion, and emotional, physical and spiritual abuse, exploitation, and indifference. This view recognizes that sexuality never stands in isolation from other considerations, and that its appropriateness in any relationship may be judged on the basis of how it does and does not enhance other aspects of the relationship.

I want to suggest that the moral qualities of a relationship are more primary for evaluating any relationship than is the sexual orientation of the persons involved. Intimate same-sex relationships may have these necessary qualities. Heterosexual ones may not. What matters are mutual responsibility, commitment, fidelity, forgiveness and generativity. Relationships with these qualities are consistent with the fundamental commitment of Christians to love of God and love of neighbor. And such relationships may signify the union between Christ and the Church.

While this may be a clear departure from the explicit teachings of Scripture and the church (and about this there is legitimate debate), it is not a departure from a fundamental precept of much of Christian ethics: love of God and neighbor are the proper bases for all other rules, guidelines, commands and judgments. This means that even the firmest, longest-standing ethical teachings may be open to reconsideration, especially when they support violation of or indifference to these fundamental commandments. It also means that it is incumbent upon me as a Christian to look beyond obvious forms and structures to the moral qualities of relationships.

Making moral judgments on the basis of something other than obvious, traditional forms supported by some aspects of Scripture does not mean complete moral relativism or permissiveness, however. This is evident in how the church has developed ways of understanding and addressing divorce and remarriage, not only pastorally but morally. Compact moral maxims may not be possible ('non-marital sexual expression is always wrong'). Instead, the church as a body and its individual members have to develop capacities for moral discernment, and these must include restraint on judgment of others so that the more complex practices of love may take place. Moral discernment is fundamentally a relational matter that entails 
respect, regard, truthfulness, responsibility and accountability. Care-filled discernment will find that no relationship exhibits all the virtues and characteristics I have indicated here, not in their fullest expression and not all the time. The need for generosity and forgiveness is always a part of Christian moral considerations, the point of which is not judgment but witness to the unfailing love of God for humankind and all of creation.

Not everyone will be convinced by the line of thought I have set out here. Some who are convinced will not grant my conclusion that homosexual relationships may meet the criteria for ethical intimate relationships. In a sense, that is as it should be. Faithful, reasonable Christians may faithfully and reasonably disagree on matters of ethics and morals, and often have. But love of God and love of neighbor put constraints on that disagreement. They mitigate against easy or obvious answers. They impel us to respect, regard and truthfulness with all others, particularly those with whom we are most at odds. 